\section{A Spontaneous Mutation at a Seedcoat Pattern Locus in the Dark Red Kidney Bean 'Red Hawk,' which Changes Seed from Self-colored to the Partially Colored Virgarcus Pattern}

\author{
E.G. Ernest ${ }^{1}$ and J.D. Kelly ${ }^{2}$ \\ Crop and Soil Sciences, Michigan State University, East Lansing MI 48824 \\ M.J. Bassett ${ }^{2}$ \\ Horticultural Sciences Department, University of Florida, Gainesville, FL 32611
}

Additional index words. Phaseolus vulgaris, seedcoat genetics, soldier dry beans

\begin{abstract}
Redcoat' soldier bean cultivar originated from off-type, virgarcus patterned seeds found in a foundation seed lot of 'Red Hawk' dark red kidney bean (Phaseolus vulgaris L.). These off-type seeds were hypothesized to be the result of a single gene mutation. A mutation at either of two loci involved in bean seedcoat pattern expression, $T$ or $Z$, could convert self-colored seedcoats to a virgarcus pattern. The results of test-crosses of 'Redcoat' and 'Red Hawk' to lines with known alleles at the seedcoat pattern loci indicate that the dominant $\boldsymbol{T}$ allele of 'Red Hawk' mutated to recessive $t$ in 'Redcoat'. The mutant $t$ gene prevents expression of red veins in wing petals due to $v r k^{\mathrm{d}}$, and enables expression of the $z$ gene (and possibly other genes) carried cryptically by 'Red Hawk'. On the basis of preliminary data, we speculate that the two types of virgarcus patterns observed (classic in 'Redcoat' and standard in the tester) may be controlled by different Bip alleles as they interact with $t z$.
\end{abstract}

The soldier bean (Phaseolus vulgaris L.) cultivar released with the name 'Redcoat' originated from a few off-type seeds found in 1999 in a foundation seed lot of 'Red Hawk,' a dark red kidney bean cultivar (Kelly et al., 1998). Unlike 'Red Hawk', which has totally colored seed, 'Redcoat' possesses white seed with a red virgarcus or soldier bean pattern on its ventral side (Fig. 1). The only other observed phenotypic difference between the cultivars is in flower color. 'Redcoat' flowers are pure white, whereas 'Red Hawk's flowers are white with faint red veins in the wing petals.

The circumstances of the discovery of 'Redcoat' aroused suspicions that it could be a seedcoat pattern mutant of 'Red Hawk', and preliminary testing supported this possibility. When grown in the greenhouse in Winter 1999-2000, the several original 'Redcoat' seeds produced progeny with seed that was true to type and which did not segregate, indicating that the off-type seeds were not the result of cross pollination. Additionally, the reaction of 'Redcoat' to inoculation with the NL 3 strain of Bean common mosaic necrosis virus (BCMV) and with races 7 and 73 of Colletotrichum lindemuthianum (Sacc. \& Magnus) Briosi \& Cav., causal agent of bean anthracnose, was identical to the reaction of 'Red Hawk' to these pathogens and different from the reactions of three other commercial soldier bean cultivars. 'Red Hawk' carries the resistance genes $I$ (BCMV) and $\mathrm{Co}-1, \mathrm{Co}-2$

Received for publication 28 Apr. 2004. Accepted for publication 14 Aug. 2004.

${ }^{1}$ Graduate student.

${ }^{2}$ Professor. with fibula arcs (Bassett and McClean, 2000). These patterns are illustrated (Fig. 2), except for expansa with fibula arcs. According to Prakken (1972), red veins in the flower are conferred by the recessive $r k^{\mathrm{d}}$ allele in combination with the background genotypes $T v$ or $t v$ for white flowers. The $r k^{\mathrm{d}}$ allele is well established as the gene conferring the dark red kidney seedcoat color, garnet brown (Smith and Madsen, 1948), typified by 'Red Hawk'.

Since two different genotypes could confer 'Red Hawk"s self-colored seed (T/- or $t Z$ Bip), a mutation at either the $T$ or $Z$ locus in 'Red Hawk' could result in the virgarcus pattern of 'Redcoat'. This study was undertaken to elucidate the genotype of 'Red Hawk' and determine which gene in 'Red Hawk' had mutated in order to produce the soldier pattern of 'Redcoat'.

\section{Materials and Methods}

Crosses were made in the greenhouse between 'Redcoat' and 'Red Hawk' and between both of these cultivars and each of three genetic testers for seedcoat pattern developed by Bassett (Bassett and Blom, 1991; Bassett, 1996): $t$ self-colored $\mathrm{BC}_{3}$ (Self-colored $t$ Z Bip V Rk), $t$ $c l z g b v$ virgarcus $\mathrm{BC}_{3}$ (Virgarcus $t z$ Bip $v R k$ ), and $t z$ bip bipunctata $\mathrm{BC}_{3} 5-593$ (Bipunctata $t$ z bip V Rk) (Table 1). For all crosses, three to four pods were harvested from each $\mathrm{F}_{2}$ plant, and the seedcoat pattern was recorded. The flower color of a sample of $37 \mathrm{~F}_{2}$ plants was also noted. No $F_{1}$ data were recorded for any of the crosses.

\section{Results and Discussion}

'Redcoat'/'Red Hawk' population. The $\mathrm{F}_{2}$ progeny of the cross 'Redcoat'/'Red Hawk' segregated in a 3:1 ratio for self-colored to virgarcus patterned seed (Table 2 ). The subset of 28 plants that were recorded as having white flowers with red veins (due to $T v r k^{\mathrm{d}}$ ) all produced self-colored seed, and the 9 plants that were recorded as having pure white flowers (due to $t v r k^{\mathrm{d}}$ ) all produced virgarcus patterned seed. This association between seed and flower color suggests that 'Red Hawk' carries a dominant $T$ gene conferring a self-colored seedcoat, colored area. With a dominant $J$, the genotype $t Z$ Bip produces self-colored or expansa patterned seed; $t Z / z$ Bip produces ambigua; $t z$ Bip produces virgarcus; $t z$ bip produces bipunctata, and $t z$ Bip Fib produces expansa
Fig. 1. Seed of 'Red Hawk' (left) and 'Redcoat' (right) bean cultivars. 


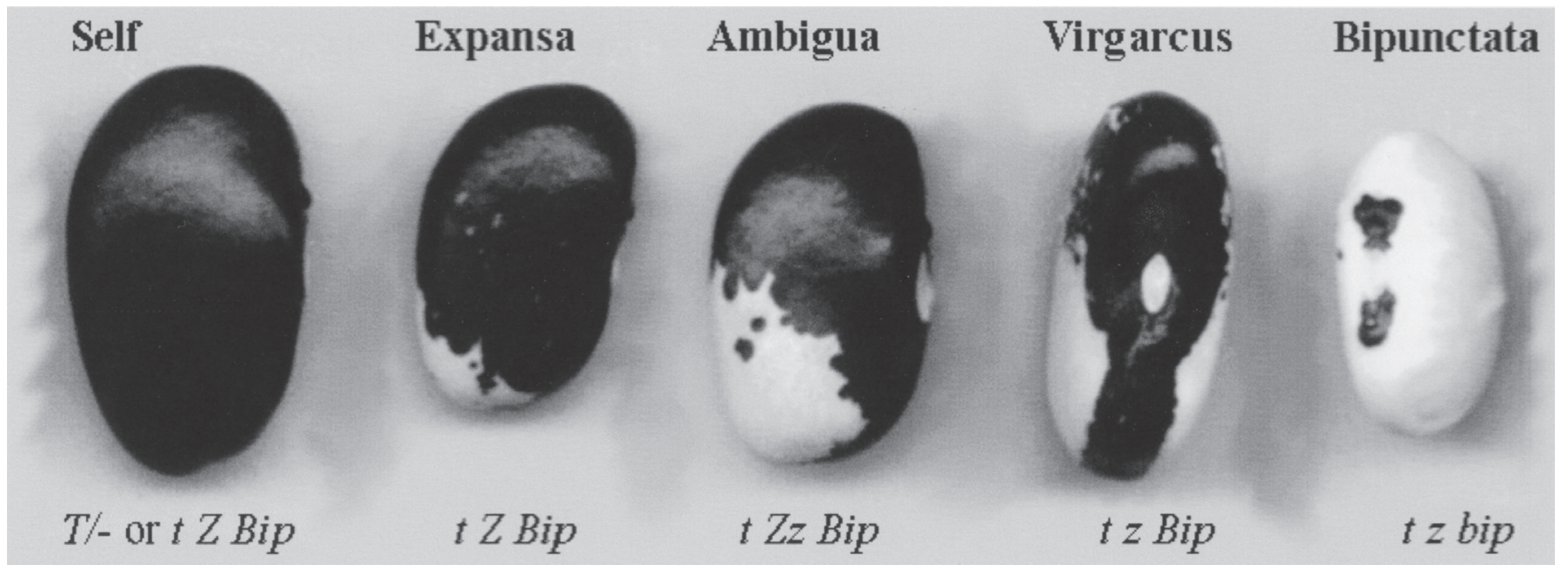

Fig. 2. Seedcoat patterns and genotypes described by Bassett and McClean (2000).

Table 1. Crosses made between 'Redcoat' and 'Red Hawk' and the seedcoat pattern tester lines.

\begin{tabular}{lcl}
\hline Female parent & & Pollen parent \\
\hline Redcoat & $\times$ & Red Hawk \\
& $\times$ & Self-colored $(t$ Z Bip $V R k)$ \\
Redcoat & $\times$ & Virgarcus $(t z$ Bip $v R k)$ \\
& $\times$ & Bipunctata $(t z$ bip $V R k)$ \\
& & \\
Red Hawk & $\times$ & Self-colored $(t Z$ Bip $V R k)$ \\
& $\times$ & Virgarcus $(t z$ Bip $v R k)$ \\
& &
\end{tabular}

whereas 'Redcoat' carries a recessive $t$ allele at this locus. When homozygous, the recessive allele in 'Redcoat', results in a virgarcus seedcoat pattern, and has a pleiotropic effect, producing white flowers. These data support the genetic hypothesis that 'Red Hawk' carries the dominant $T$ allele, which masks expression of the recessive $z$ allele carried by this cultivar. The dominant $T$ allele in 'Red Hawk' mutated to a recessive $t$ in 'Redcoat', allowing $z$ to be expressed and produce the virgarcus pattern. The failure of 'Redcoat' to express red veins in the flower contradicts the findings of Prakken (1972), who reported red flower vein expression with the genotype $t v r k^{\mathrm{d}}$. Our hypothesis is that the new mutant gene for $t$ in 'Redcoat' interacts differently with $r k^{\mathrm{d}}$ from the $t$ gene in 'Soldaat K' used by Prakken and may be a new allele at $T$.

Flower color in 'Redcoat' and 'Red Hawk' by seedcoat pattern tester $F_{2}$ populations. The seedcoat pattern tester lines are all white flowered since they carry the recessive $t$ allele. However, the 'Red Hawk'/self-colored and 'Red Hawk'/bipunctata $F_{2}$ populations included plants with violet, white, and red-veined white flowers (Table 3). The 'Red Hawk'/virgarcus $F_{2}$ plants had either white flowers or red-veined white flowers. This suggests that 'Red Hawk' carries the dominant $T$ allele, since violet flowers (conferred by $V$ ) would not be expressed if 'Red Hawk' possessed $t$. Violet flowers were not present in the 'Red Hawk'/virgarcus $\mathrm{F}_{2}$ plants since both 'Red Hawk' and the tester line carry $v$. There were no plants with violet flowers in the 'Redcoat'/self-colored, 'Red- coat'/virgarcus or 'Redcoat'/bipunctata $\mathrm{F}_{2}$ populations, which supports the hypothesis that 'Redcoat' carries $t$.

'Red Hawk'/self, 'Red Hawk'/virgarcus, and 'Red Hawk'/bipunctata $F_{2}$ populations. Seven different seedcoat patterns were observed in the $\mathrm{F}_{2}$ populations of 'Red Hawk' and 'Redcoat' by seedcoat pattern tester stocks (Fig. 3). Three distinct virgarcus patterns were observed: tester-like virgarcus, 'Redcoat'-like virgarcus, and weak virgarcus. Seedcoat pattern frequencies in the 'Red Hawk'/tester $F_{2}$ populations support the theory that 'Red Hawk' carries $T$ (Table 2). If 'Red Hawk's self-colored seedcoat were conferred by the genotype $t Z$ $B i p$, no partly colored patterns other than expansa would be expected in the 'Red Hawk'/self $\mathrm{F}_{2}$ population, since the self-colored tester has this same genotype. However, a few individuals in the population expressed the virgarcus and weak virgarcus patterns (Fig. 2, Table 4). If 'Red Hawk' carries $T z$, there is an expected segregation ratio of 15 self-colored and expansa : 1 virgarcus and weak virgarcus in the 'Red Hawk'/self-colored tester $\mathrm{F}_{2}$ population, as was observed (Table 4). Similarly, if 'Red Hawk' carries $T z$, there is an expected segregation ratio of 3 self-colored: 1 partly colored in the 'Red
Hawk'/virgarcus and 'Red Hawk'/bipunctata $F_{2}$ populations. The observed values for the 'Red Hawk'/bipunctata population fit a 3:1 ratio, but the data for the 'Red Hawk'/virgarcus population do not quite fit a $3: 1$ ratio according to the chi-square goodness of fit test (Table 2). 'Red Hawk' appears to carry the $z$ gene for 'Redcoat's virgarcus pattern cryptically since all of the 'Red Hawk'/tester $\mathrm{F}_{2}$ populations contained some plants expressing 'Redcoat' like virgarcus patterned seed (Fig. 3).

'Redcoat'/self, 'Redcoat'/virgarcus, and 'Redcoat'/bipunctata $F_{2}$ populations. The frequencies of the different seedcoats patterns in the 'Redcoat'/self, 'Redcoat'/virgarcus and 'Redcoat'/bipunctata $F_{2}$ populations are given in Table 4. Unexpectedly, $27 \mathrm{~F}_{2}$ plants from the 'Redcoat'/virgarcus cross expressed the ambigua pattern and seven plants expressed the bipunctata pattern. Segregation in this cross of two virgarcus patterned lines suggests that the alleles conferring 'Redcoat's virgarcus pattern are not the same as those carried by the virgarcus tester line.

The seedcoat pattern of 'Redcoat' is different from that of the virgarcus tester. The colored area on seeds of the virgarcus tester completely encircles the hilum, whereas in seed

Table 2. Chi-square goodness of fit tests of ratio of 3 self-colored (T/-) : 1 partly-colored $(t / t)$ in the 'Red Hawk'/'Redcoat', 'Red Hawk'/virgarcus, and 'Red Hawk'/bipunctata $\mathrm{F}_{2}$ generations.

\begin{tabular}{lcccccccc}
\hline Seedcoat & \multicolumn{2}{c}{ RH/RC } & & \multicolumn{2}{c}{ RH/virgarcus } & & \multicolumn{2}{c}{ RH/bipunctata } \\
\cline { 2 - 3 } pattern & Observed & Expected & & Observed & Expected & & Observed & Expected \\
\hline Self colored $(T /-)$ & 211 & 204.75 & & 110 & 122.25 & & 63 & 63.75 \\
Partly colored $(t / t)$ & 62 & 68.25 & & 53 & 40.75 & & 22 & 21.25 \\
Chi-square $(p$ value $)$ & $\mathbf{0 . 7 6}$ & $(0.382)$ & & $\mathbf{4 . 9 1}$ & $(0.027)$ & $\mathbf{0 . 0 4}$ & $(0.851)$ \\
\hline
\end{tabular}

${ }^{2} \mathrm{RH}=$ 'Red Hawk'; RC = 'Redcoat'.

Table 3. Flower color in six test crosses. Inferred $\mathrm{F}_{1}$ genotypes and segregation for three flower color classes in the $\mathrm{F}_{2}$

\begin{tabular}{|c|c|c|c|c|}
\hline \multirow[b]{2}{*}{ Cross $^{z}$} & \multirow{2}{*}{$\begin{array}{l}\text { Genetic } \\
\text { hypothesis } \\
\text { of } F_{1} \text { plants }\end{array}$} & \multicolumn{3}{|c|}{$\begin{array}{c}\text { Flower color classes in } \mathrm{F}_{2} \\
\text { (genotypes at } T V \text { and } R k \text { loci) }\end{array}$} \\
\hline & & $\begin{array}{c}\text { Violet } \\
(T /-V /--/-)\end{array}$ & $\begin{array}{c}\text { White }^{\mathrm{y}} \\
(t v-/- \text { or } T /-v R k /-)\end{array}$ & $\begin{array}{l}\text { White/red veins } \\
\qquad\left(T /-v r k^{\mathrm{d}}\right)\end{array}$ \\
\hline$\overline{\mathrm{RH}} / \mathrm{self}$ & $T / t V / v R k / r k^{\mathrm{d}}$ & $\mathrm{X}$ & $\mathrm{X}$ & $\mathrm{X}$ \\
\hline RH/virgarcus & $T / t v / v R k / r k^{\mathrm{d}}$ & & $X$ & $X$ \\
\hline RH/bipunctata & $T / t V / v R k / r k^{\mathrm{d}}$ & $\mathrm{X}$ & $\mathrm{X}$ & $X$ \\
\hline $\mathrm{RC} /$ self & $t / t V / v R k / r k^{\mathrm{d}}$ & & $X$ & \\
\hline $\mathrm{RC} /$ virgarcus & $t / t v / v R k / r k^{\mathrm{d}}$ & & $X$ & \\
\hline RC/bipunctata & $t / t V / v R k / r k^{\mathrm{d}}$ & & $\mathrm{X}$ & \\
\hline
\end{tabular}

${ }^{2} \mathrm{RH}=$ 'Red Hawk'; RC = 'Redcoat'.

${ }^{y}$ Contrary to the findings of Prakken (1972), plants with $t r k^{\mathrm{d}}$ failed to express red veins. 


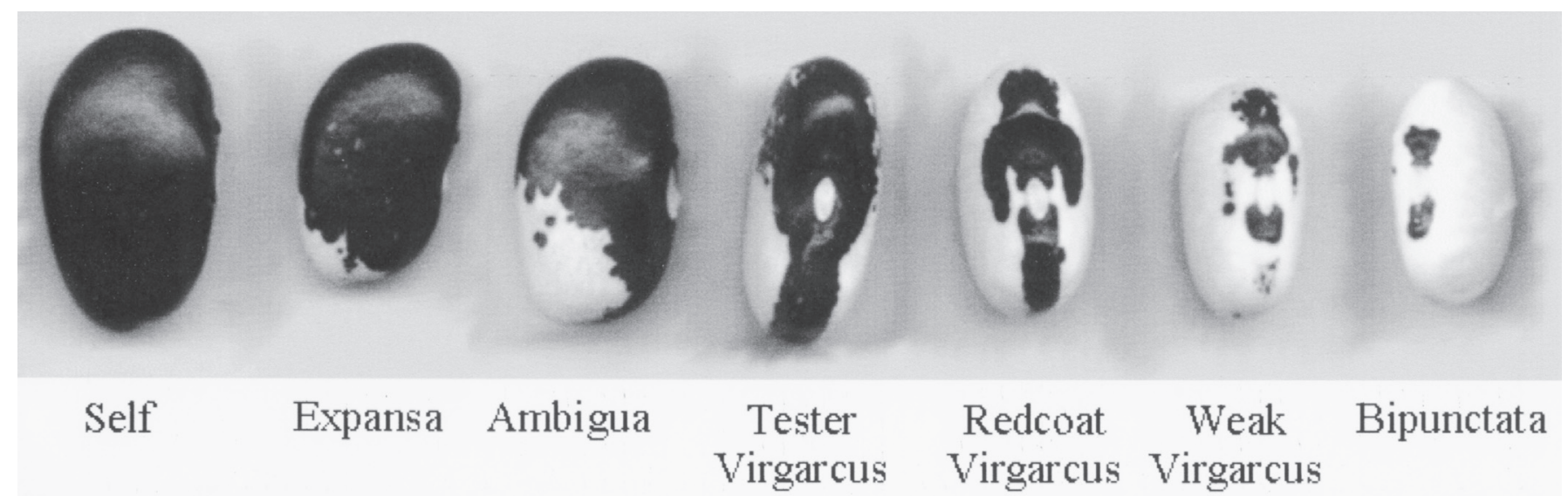

Table 4. Seedcoat pattern frequency in the 'Red Hawk' and 'Redcoat' seedcoat pattern tester $F_{2}$ populations.

\begin{tabular}{lcrrrrr}
\hline Seedcoat & \multicolumn{7}{c}{ Cross $^{\mathbf{z}}$} \\
\cline { 2 - 7 } pattern & RH/self & RH/vir & RH/bip & RC/self & RC/vir & RC/bip \\
\hline Self & 78 & 110 & 63 & 42 & 0 & 0 \\
Expansa & 4 & 0 & 0 & 36 & 0 & 0 \\
Ambigua & 0 & 17 & 5 & 26 & 27 & 0 \\
Redcoat virgarcus & 3 & 11 & 9 & 13 & 31 & 58 \\
Tester virgarcus & 2 & 20 & 0 & 6 & 24 & 0 \\
Weak virgarcus & 1 & 5 & 5 & 5 & 13 & 40 \\
Bipunctata & 0 & 0 & 3 & 0 & 7 & 22 \\
Total & 88 & 163 & 85 & 128 & 102 & 120 \\
\hline
\end{tabular}

${ }^{2} \mathrm{RH}=$ 'Red Hawk'; RC = 'Redcoat'; self, self-colored; vir, virgarcus; bip, bipunctata.

${ }^{y}$ For genotypes $T /-Z /-, t / t$ Z/-, and $T /-z / z$ (self-colored and expansa) there were 82 observed plants, and for genotype $t / t z / z$ (Redcoat virgarcus, tester virgarcus, and weak virgarcus) 6 plants were observed. For data $82: 6$, the chi-square $(15: 1)=0.049, p=0.83$.

of 'Redcoat' the arcs of color, which extend from the caruncular end of the seed, do not join with the micropyle stripe (Fig. 3). Since the virgarcus tester was derived from a cross between 5-593 and a plant with bipunctata patterned seed (PI 527212), rather than 5-593 and a plant expressing a virgarcus pattern, it is possible that this tester does not carry the same $t$ and $z$ genes as a seed with the classic soldier or virgarcus pattern displayed by 'Redcoat'. Plants expressing the tester-virgarcus pattern occurred in the 'Red Hawk'/self, 'Red Hawk'/ virgarcus, 'Redcoat'/self and 'Redcoat'/virgarcus $\mathrm{F}_{2}$ populations. This suggests that the Bip allele from 5-593 is required for the expression of tester-virgarcus, and that 'Redcoat' and the tester differ at this locus.

Results from the virgarcus ('Redcoat')/bipunctata cross are similar to those reported by Lamprecht (1940) for a virgarcus/bipunctata cross, and different from those previously obtained by Bassett (1996). Bassett (1996) observed a 3:1 segregation ratio for virgarcus: lation. Lamprecht (1940), however, observed nine different seedcoat patterns segregating in the virgarcus/bipunctata $F_{2}$ population, including an intermediate pattern (arcus), which resembles the weak virgarcus class observed in this study. In order to explain his results Lamprecht (1940) proposed that the Bip locus interacts with alleles at an independent locus, which he called $A r c$. We speculate that the tester lines may carry an allele at $A r c$ that is different from the Arc gene of Lamprecht (1940).

\section{Conclusions}

'Red Hawk' dark red kidney bean carries the dominant $T$ allele, which confers a self colored seedcoat and masks the expression of the $z$ seedcoat pattern gene (and possibly others) that the cultivar carries. In 'Redcoat' the $T$ allele of 'Red Hawk' mutated to recessive bipunctata in his virgarcus/bipunctata $F_{2}$ popu-
Fig. 3. Seedcoat patterns observed in the 'Red Hawk' and 'Redcoat' by seedcoat pattern tester $\mathrm{F}_{2}$ populations.

$t$, resulting in a virgarcus patterned seedcoat and suppressing the expression of red veins in the flowers. The genes conferring 'Redcoat's virgarcus pattern are different from those of the virgarcus tester used in the study. We propose that 'Redcoat' ('Red Hawk') and the testers differ at the Bip locus and possibly at the Arc locus as well.

\section{Literature Cited}

Bassett, M.J. 1996. Inheritance of the partly colored seedcoat pattern, bipunctata, in common bean. J. Amer. Soc. Hort. Sci. 121:1032-1034.

Bassett, M.J. and A. Blom. 1991. A new genotype for white seed coat discovered in 'Early Wax' snap bean. J. Amer. Soc. Hort. Sci. 116:131-136.

Bassett, M.J. and P. McClean. 2000. A brief review of the genetics of partly colored seed coats in common bean. Annu. Rpt. Bean Improve. Coop. 43:99-101.

Kelly, J.D., G.L. Hosfield, G.V. Varner, M.A. Uebersax, R.A. Long, and J. Taylor. 1998. Registration of 'Red Hawk' dark red kidney bean. Crop Sci. 38:280-281.

Lamprecht, H. 1940. Regarding the genetics of Phaseolus vulgaris XVI. Further contributions regarding the heredity of partial color. Hereditas 26:277-291.

Prakken, R. 1972. Inheritance of colours in Phaseolus vulgaris L. III. On genes for red seedcoat colour and a general synthesis. Meded. Landbouwhogeschool Wageningen 72-79:1-82.

Smith, F.L. and C.B. Madsen. 1948. Seed-color inheritance in beans. J. Hered. 39:191-194. 